\title{
Relationship between workloads and presenteeism among nursing workers
}

\author{
Relação entre cargas de trabalho e o presenteísmo entre trabalhadores de enfermagem \\ Relación entre cargas de trabajo y presentismo entre trabajadores de enfermería
}

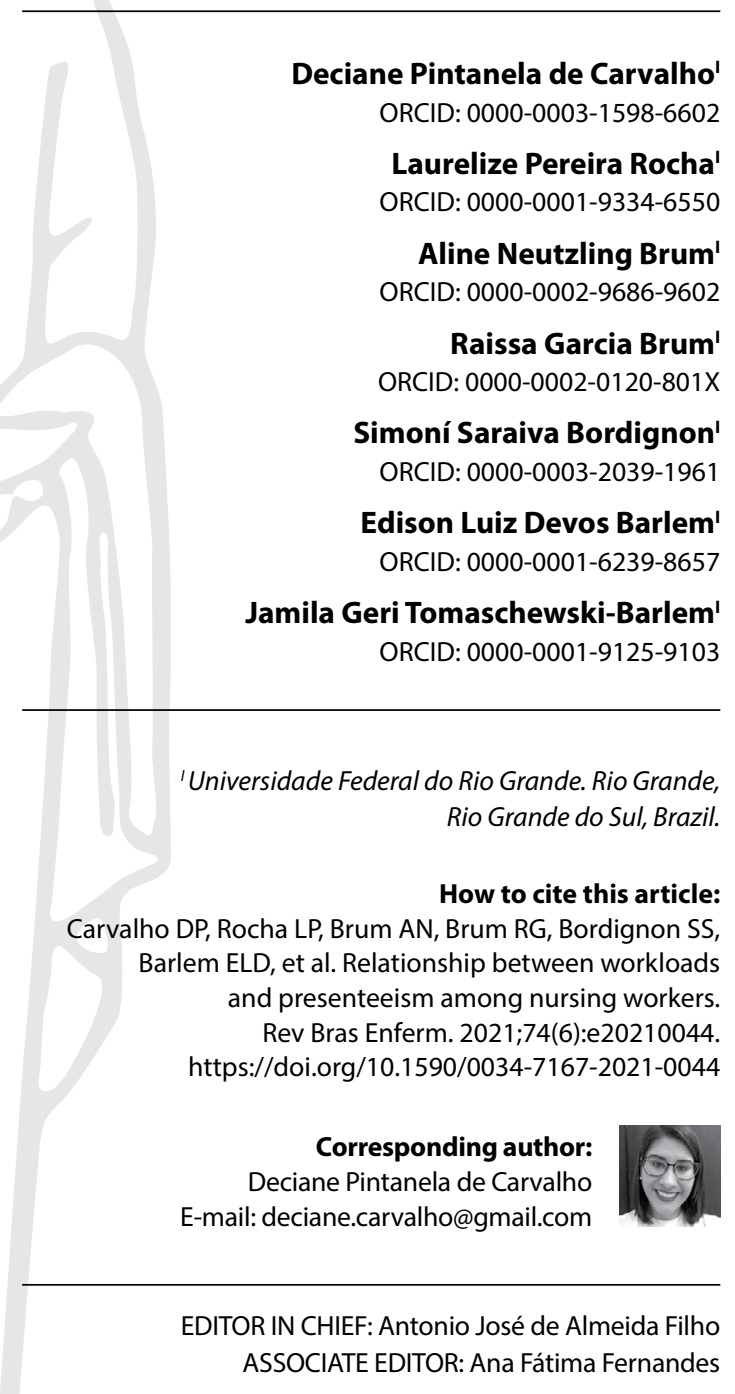

Submission: $02-12-2021$

\begin{abstract}
Objective: to analyze the relationship between exposure to workloads and presenteeism among nursing workers in the socio-environmental context of university hospitals. Method: this is a quantitative, cross-sectional and analytical study with 355 nursing workers from two university hospitals in southern Brazil. Data were collected from November 2019 to February 2020. The Workload Scale in Nursing Activities and the Work Limitations Questionnaire were used. Descriptive statistics, variance analysis and Pearson's correlation test were used. Results: there was a significant correlation between chemical loads and time management: biological loads and time management, physical demand and productivity loss; physiological loads and mental and interpersonal demand, production demand and loss of productivity; psychological loads and production demand. Conclusions: there is a relationship between workloads and nursing presenteeism, verified by limitations and loss of productivity. Descriptors: Presenteeism; Workload; Nursing, Team; Hospitals, University; Nursing.
\end{abstract}

\section{RESUMO}

Objetivo: analisar a relação entre a exposição às cargas de trabalho e o presenteísmo entre trabalhadores de enfermagem no contexto socioambiental de hospitais universitários. Método: estudo quantitativo, transversal e analítico, com 355 trabalhadores de enfermagem de dois hospitais universitários no sul do Brasil. A coleta de dados ocorreu de novembro de 2019 a fevereiro de 2020. Utilizou-se a Escala de Cargas de Trabalho nas Atividades de Enfermagem e o Work Limitations Questionnaire. Empregou-se estatística descritiva, análise de variância e teste de correlação de Pearson. Resultados: verificou-se correlação significativa entre as cargas químicas e a gerência de tempo; cargas biológicas e gerência de tempo, demanda física e perda de produtividade; cargas fisiológicas e demanda mental e interpessoal, demanda de produção e perda de produtividade; cargas psíquicas e demanda de produção. Conclusão: existe relação entre as cargas de trabalho e o presenteísmo na enfermagem, verificado por limitações e perda de produtividade.

Descritores: Presenteísmo; Carga de Trabalho; Equipe de Enfermagem; Hospitais Universitários; Enfermagem.

\section{RESUMEN}

Objetivo: analizar la relación entre la exposición a la carga de trabajo y el presentismo entre los trabajadores de enfermería en el contexto socioambiental de los hospitales universitarios. Métodos: estudio cuantitativo, transversal y analítico con 355 trabajadores de enfermería de dos hospitales universitarios del sur de Brasil. La recolección de datos se realizó de noviembre de 2019 a febrero de 2020. Se utilizó la Escala de Carga de Trabajo para Actividades de Enfermería y el Work Limitations Questionnaire. Se utilizó estadística descriptiva, análisis de varianza y prueba de correlación de Pearson. Resultados: hubo una correlación significativa entre las cargas químicas y la gestión del tiempo; cargas biológicas y gestión del tiempo, demanda física y pérdida de productividad; cargas fisiológicas y demanda mental e interpersonal, demanda de producción y pérdida de productividad; cargas psíquicas y demanda de producción. Conclusiones: Existe una relación entre cargas de trabajo y presentismo en enfermería, verificada por limitaciones y pérdida de productividad. Descriptores: Presentismo; Carga de Trabajo; Grupo de Enfermería; Hospitales Universitarios; Enfermería. 


\section{INTRODUCTION}

In the health area, working conditions in which assistance is developed, characteristics related to the environment and nursing work activities expose workers to different workloads ${ }^{(1)}$. The definition of workloads comprises the elements of the work environment itself, which, through their interaction with workers, are capable of generating physical and psychological strain to their health ${ }^{(2)}$.

The presence of workloads in the work environment also generates loss of productivity among nursing workers, limitations and difficulty in the development of activities ${ }^{(3)}$. This decrease in productivity, as well as reduction in quality of care, characterize the phenomenon called presenteeism, which refers to the fact that workers develop work, despite being sick, in the face of work overload, lack of support from the head, physical and mental conditions of workers ${ }^{(4)}$.

The hospital environment is the workplace with the highest prevalence of presenteeism ${ }^{(5)}$, and among the nursing team, nurses are considered the most presentist ${ }^{(4)}$. Other studies highlight that presenteeism is a challenge for nursing management, which should plan and manage work, so that it does not burden workers, maintaining an adequate number of workers and reducing tasks, due to the fact that presenteeism is preceded by demands for work, exhaustion and exhaustion ${ }^{(6-7)}$.

Presenteeism was evidenced in a study that indicates that nurses working in hospitals and Primary Health Care in Brazil, Portugal and Spain develop their work even though they have some disease ${ }^{(8)}$. Similarly, presenteeism was presented among a multidisciplinary team of an Intensive Care Unit, resulting from physical and psychological health problems ${ }^{(9)}$. Considering that presenteeism occurs in different contexts, it is necessary to deepen this theme in university hospitals, due to its characteristics that involve patient care along with the demands of teaching, research and extension linked to the University.

Furthermore, nursing presenteeism has been discussed internationally, because it compromises workers' health and the activities developed in patient care ${ }^{(10)}$. This may be linked to the presence of nursing workloads, resulting from the conditions in which the activities are performed; therefore, this study sought to relate exposure to workloads with the limitations that generate presenteeism. It is understood that, in nursing, there is a commitment to quality of care, causing workers to perform the work, despite feeling changes in their health. Thus, this analysis will allow improvements in working conditions in university hospitals and, consequently, the reduction of exposure to workloads, minimizing the negative impacts on workers' health, illness and presenteeism.

\section{OBJECTIVE}

To analyze the relationship between exposure to workloads and presenteeism among nursing workers in the socio-environmental context of university hospitals.

\section{METHODS}

\section{Ethical aspects}

This study was approved by an Institutional Review Board, and the ethical aspects were respected, recommending Resolution
$466 / 2012$ of the Brazilian National Health Council (Conselho Nacional de Saúde).

\section{Study design, period, and location}

This is a cross-sectional and analytical quantitative study, developed from the STROBE tool in two university hospitals linked to public universities, located in two municipalities in southern Brazil, identified by $\mathrm{H} 1$ and $\mathrm{H} 2$. Data were collected between November 2019 and February 2020.

\section{Population and sample; inclusion and exclusion criteria}

For the sample calculation, we considered the population of 752 nursing workers, $366 \mathrm{H} 1$ and $376 \mathrm{H} 2$ workers, 174 nurses, 448 nursing technicians and 120 nursing assistants. Therefore, the reliability level of $95 \%$ was used, obtaining as a minimum sample 255 participants ${ }^{(11)}$. The sampling was non-probabilistic type for convenience, seeking to reach the largest number of participants in the morning, afternoon and evening shifts, reaching a sample of 355 participants. Among them are 95 nurses, 229 nursing technicians and 31 nursing assistants.

The inclusion criteria were to work in the following assistance units: Medical Clinic, Surgical Clinic, Emergency Service, Emergency Network, Obstetric Clinic, Maternity, Pediatric Clinic, Surgical Center and (general and neonatal) Intensive Care Unit. The units were selected by approximation of the work processes. As exclusion criteria are being on vacation or leave of any kind at the time of data collection.

It is noteworthy that Emergency Care Service and Emergency and Emergency Network workers were maintained as different working units, because, the Emergency Network despite being considered the entrance door of the hospital, receives patients from another emergency care, besides being subdivided into three sectors, which increases the number of workers, and differentiates it from the Emergency Care Service. In the other units, there was no differentiation of workers between the two hospitals for data analysis, due to the equivalence of work processes.

\section{Study protocol}

Data collection occurred by a previously trained team, which distributed 400 instruments to workers in the work sectors individually, obtaining a return of 372 . Of these, two were excluded for incorrect filling, eight were returned blank and one for refusal. For data collection, we used an instrument elaborated by the author with sociodemographic and labor variables, containing openended and closed-ended questions, including: gender, age, job role and leadership position.

For analysis of presenteeism, the Work Limitations Questionnaire (WLQ) was used, which assesses the frequency of difficulty or ability to perform work-related tasks, identifying presenteeism, an instrument that can only be used with the permission of the authors, for this purpose, it was necessary to sign a Confidentiality Disclosure Agreement. The WLQ consists of 25 items in five questions, distributed in four limitation domains at work: time management, physical demand domain, mental-interpersonal demand and production demand ${ }^{(12)}$. This instrument was chosen 
for the study, considering that it is able to identify the limitations for work, which enables the development of specific actions to the demands presented by workers.

For analysis of workloads, the Workload Scale in Nursing Activities (ECTAE - Escala de Cargas de Trabalho nas Atividades de Enfermagem) was used, designed to analyze situations of exposure to workloads in the socioenvironmental context of university hospitals. ECTAE consists of 22 items distributed in six constructs of workloads ${ }^{(2)}$. The F1 construct, Psychological loads, addresses administrative, care and teaching activities, research and extension, communication, guidance and supervision, teamwork, constant attention, psychological and/or moral violence, tension at work; F2, Physiological loads, refers to weight manipulation, patient transport, physical exertion; F3, Biological loads, assesses the presence of microorganisms, secretions, body fluids and procedures; F4, Mechanical loads, refers to suffering physical violence, falls and accidents at work; F5, Physical loads, analyzes the infrastructure, lighting, physical space, materials, waste disposal and electric shock; F6, Chemical loads, addresses the preparation and administration of medicines and the handling of cleaning and disinfecting materials.

ECTAE items are assessed by two five-point Likert scales, of intensity (not intense $=0$; not very intense $=1$; intense $=2$; very intense $=3$; extremely intense $=4$ ) and frequency (not frequent $=0$; little frequent $=1$; frequent $=2$; very frequent $=3$; extremely frequent $=4$ ). This scale was validated with Cronbach's alpha of 0.87 , the adequacy measure of the sample obtained (KMO) was 0.87 and Bartlett's test of sphericity (BTS) identified statistical significance of 0.001 .

\section{Analysis of results, and statistics}

The data were entered Microsoft Office Excel 2020, after being transported to Statistical Package for Social Sciences, version 24 to perform statistical analyses. The WLQ analysis followed the manual provided by the author of the instrument. This instrument has a rule for the questionnaire feasibility after being filled out, referring to a minimum number of responses for each domain in need of exclusion, identifying the WLQ index, which allows determining the percentage of lost productivity of workers ${ }^{(12)}$.

For this, it was verified the instruments that had the minimum number of answers for each domain, from this rule six questionnaires were excluded. Based on this rule, six questionnaires were excluded. Thus, 355 participants were considered to perform the study.

Descriptive statistics were performed in the analysis of sociodemographic, labor and ECTAE characterization data by means of distribution of relative and absolute frequencies, mean and standard deviation. Descriptive statistics were also used for WLQ data, through distribution of relative and absolute frequencies, position measurements, such as mean, median and quartiles, such as standard, minimum and maximum deviation, allowing the analysis of presenteeism, according to the labor characteristics of nursing workers ${ }^{(13)}$.

The normality of the numerical data was tested using the Kolmogorov-Smirnov test $(p=0.000)$, verifying normal distribution and using parametric tests for inferential analyzes. Variance analysis (ANOVA) was performed to compare the means obtained by workers in WLQ items according to working units, job role and position of leadership. Pearson's correlation test was used to analyze the relationship between workloads and presenteeism, adopting $r$ between -1 and 1. $P$ value of $<0.05$ was adopted as statistical significance in all analyses ${ }^{(13)}$.

\section{RESULTS}

According to the sociodemographic characteristics of the 355 nursing workers, 290 (81.7\%) were female and 65 (18.3\%) males, mean age of 38.9 years ( $S D \pm 8.6$ years). Workloads that presented the highest intensity, very intense exposure, were to biological loads with a mean of $3.0(\mathrm{SD}=0.95)$. Physiological and chemical loads were identified as intense exposure, with means of 2.53 $(S D=1.12)$ and $2.36(S D=1.10)$. Psychological loads presented a mean of $1.83(S D=0.91)$ and the mean physical loads of 1.40 $(\mathrm{SD}=1.07)$, being identified as - little intense exposure - and finally, the mechanical loads were identified as - no intense exposure - and presented a mean of $0.92(S D=0.93)$. Table 1 shows the intensity of workloads according to the categories of work, showing that nursing technicians identified a higher mean intensity in relation to the other categories of work for biological loads, 3.13 ( $\mathrm{SD}=0.91$ ), chemical loads, $2.64(\mathrm{SD}=1.08)$, and physiological loads, $2.64(S D=1.11)$. Nurses present higher mean intensity for psychological loads - $2.29(\mathrm{SD}=0.94)$ and physical loads - 1.54 $(S D=1.17)$ in relation to nursing technicians and auxiliaries. Nursing assistants presented higher mean intensity for mechanical loads, 1.11 (0.91) in relation to nurses and nursing technicians.

Table 2 shows the distribution of nursing workers according to the values obtained in the WLQ. Presenteeism is identified by the mean productivity loss of $5.7 \%$, and $75 \%$ of workers had $7.5 \%$ of lost productivity. In the physical demand domain, there was a mean of $43.7 \%$ limitation and $75 \%$ of workers presented physical limitation of $66.6 \%$.

In Table 3, the WLQ index and limitation domains were verified among nursing workers according to their work characteristics. It was identified that, according to working units, the Emergency Network was the unit with the highest mean limitation in the domains time management (27.5\%), production demand (21.9\%) and also the highest mean lost productivity (6.9\%). In the physical demand domain, the unit with the highest mean limitation was the Emergency Care Service (51.1\%). In the mental-interpersonal demand domain, the highest mean limitation was in the Medical Clinic Unit (21.7\%).

Regarding the role performed by workers, it is evident that nurses presented higher mean lost productivity (7.0\%), followed by nursing technicians (5.3\%) and nursing assistants (4.7\%). Moreover, nurses also had higher mean limitation in the domains of time management (27.1\%), mental-interpersonal demand (22.2\%), production demand (22.9\%). The nursing assistants presented a higher mean limitation in the physical demand domain (51.7\%). It is noteworthy that nurses who hold leadership positions have higher mean lost productivity (10.5\%) as well as in other WLQ items.

The ANOVA test was performed, verifying a significant difference between work characteristics of nursing workers and the WLQ evaluation items. The working unit showed a statistically significant difference with time management $(p=0.008)$, mental-interpersonal demand $(p=0.027)$, production demand $(p=0.010)$ and productivity loss index $(p=0.010)$. There were also significant differences between job role and time management $(p=0.002)$, mental-interpersonal 
demand $(p=0.003)$, production demand $(p=0.001)$ and WLQ index $(p=0.001)$. A significant difference was identified between the variable holding the position of leadership and time management $(p=0.021)$, mental-interpersonal demand $(p=0.001)$, production demand $(p=0.001)$ and WLQ $(p=0.001)$ (Table 4).

Table 5 shows the positive relationship between physical workloads through the item of instrument "Q03. Handle cleaning and disinfection products, equipment and materials such as formaldehyde, sodium hypochlorite, soaps, peracetic acid, alcohol" and the domain time management $(r=0.13, p<0.015)$. Therefore, when this chemical load increases during nursing activities, it generates an increase in time limitation among nursing workers.

Another item that presented a positive correlation with time management limitation was "Q05. Use latex gloves to perform invasive and noninvasive procedures in patients and product manipulation" $(r=0.10, p<0.042)$. A question related to exposure to biological loads identifies that, when the development of activities that require latex gloves increases, the time limitation of workers increases.

The negative relationship was identified between the biological load using item "Q10. Have contact with secretions at the time of dressings, care with drains and oral, nasal or tracheal aspiration" and the limitation physical demand $(r=-0.12, p<0.018)$. Therefore, it was evidenced that, when exposure to biological load increases, the physical limitation of workers decreases.

The biological load, through item "Q11. Providing care to patients affected by microorganisms (viruses, bacteria, fungi) and patients in contact precaution, aerosols and droplets", presented a negative correlation with the domain time management $(r=-0.10$, $p<0.042$ ), physical demand domain $(r=-0.14, p<0.007)$ and loss of productivity $(r=-0.12, p<0.019)$. Therefore, it was identified that, when there is increased exposure to these biological loads, the workers presented a decrease in limitations related to time demand, physical demand and loss of productivity.

The item "Q15. Transporting the patient from the stretcher to the bed or wheelchair, transporting patients and equipment" showed a positive correlation with the limitation domains production demand $(r=0.11, p<0.038)$, mental-interpersonal demand $(r=0.15$, $\mathrm{p}<0.004)$ and productivity loss index $(r=0.15, p<0.004)$. This item characterizes exposure to physiological load, evidencing that, when this load increases, the limitations of mental-interpersonal demand, production demand and loss of productivity among workers increase.
Table 1 - Intensity of workloads by job category, Rio Grande, Rio Grande do Sul, Brazil, $2020(\mathrm{~N}=355)$

\begin{tabular}{|c|c|c|c|c|c|c|}
\hline \multirow[t]{2}{*}{ ECTAE Items } & \multicolumn{2}{|c|}{ Nurses } & \multicolumn{2}{|c|}{$\begin{array}{l}\text { Work category } \\
\text { Nursing } \\
\text { technicians }\end{array}$} & \multicolumn{2}{|c|}{$\begin{array}{l}\text { Nursing } \\
\text { assistants }\end{array}$} \\
\hline & $\overline{\mathbf{x}}$ & SD & $\overline{\mathbf{x}}$ & SD & $\overline{\mathbf{x}}$ & SD \\
\hline Biological loads & 2.87 & 1.04 & 3.13 & 0.91 & 2.60 & 0.91 \\
\hline Mechanical loads & 1.08 & 1.13 & 0.83 & 0.83 & 1.11 & 0.91 \\
\hline Chemical loads & 1.72 & 0.93 & 2.64 & 1.08 & 2.35 & 0.98 \\
\hline Physical loads & 1.54 & 1.17 & 1.35 & 1.06 & 1.34 & 0.81 \\
\hline Psychological loads & 2.29 & 0.94 & 1.70 & 0.84 & 1.48 & 0.83 \\
\hline Physiological loads & 2.32 & 1.19 & 2.64 & 1.11 & 2.48 & 1.05 \\
\hline
\end{tabular}

Table 2 - Values obtained by nursing workers in Work Limitations Questionnaire items, Rio Grande, Rio Grande do Sul, Brazil, 2020 ( $N=355$ )

\begin{tabular}{lcccccc}
\hline WLQ Domains & $\mathbf{N}$ & $\overline{\mathbf{X}}$ & SD & Q1 & Med & Q3 \\
\hline WLQ Index & 355 & 5,7 & 3,8 & 3,24 & 5,1 & 7,5 \\
Time management & 355 & 21,3 & 20,0 & 5 & 15 & 31,2 \\
Physical demand & 355 & 43,7 & 28,3 & 20,8 & 41,6 & 66,6 \\
Mental-interpersonal demand & 355 & 17,3 & 17,0 & 5,5 & 13,8 & 25 \\
Production demand & 355 & 16,7 & 17,9 & 5 & 10 & 25 \\
\hline
\end{tabular}

Note: $\bar{X}$ - mean; SD - standard deviation; Q1 - first quartile; Med - median; Q3 - third quartile; WLQ - Work Limitations Questionnaire.

Table 3 - Values obtained in Work Limitations questionnaire items by nursing workers according to their work characteristics, Rio Grande, Rio Grande do Sul, Brazil, 2020 (N=355)

\begin{tabular}{|c|c|c|c|c|c|c|c|c|c|c|c|}
\hline \multirow{3}{*}{ Variables } & \multirow{3}{*}{$\mathbf{n}$} & \multicolumn{4}{|c|}{ Management } & \multicolumn{4}{|c|}{ Demand } & \multirow{2}{*}{\multicolumn{2}{|c|}{ WLQ }} \\
\hline & & \multicolumn{2}{|c|}{ Time } & \multicolumn{2}{|c|}{ Physical } & \multicolumn{2}{|c|}{$\begin{array}{c}\text { Mental- } \\
\text { Interpersonal }\end{array}$} & \multicolumn{2}{|c|}{ Production } & & \\
\hline & & $\overline{\mathbf{x}}$ & SD & $\overline{\mathbf{x}}$ & SD & $\overline{\mathbf{X}}$ & SD & $\overline{\mathbf{x}}$ & SD & $\overline{\mathbf{x}}$ & SD \\
\hline \multicolumn{12}{|l|}{ Working unit } \\
\hline $\mathrm{OB}$ & 20 & 20.2 & 15.9 & 37.9 & 30.4 & 17.4 & 19.8 & 12.2 & 13.5 & 5.0 & 3.8 \\
\hline MAT & 49 & 25.1 & 20.4 & 42.8 & 26.6 & 19.3 & 18.2 & 18.8 & 18.1 & 6.3 & 3.9 \\
\hline PU & 28 & 14.3 & 13.9 & 44.4 & 36.3 & 10.4 & 8.7 & 7.5 & 9.7 & 3.9 & 2.6 \\
\hline ES & 31 & 12.0 & 11.7 & 51.1 & 25.8 & 12.6 & 10.3 & 13.1 & 14.0 & 4.8 & 2.6 \\
\hline MCU & 56 & 24.4 & 19.4 & 41.2 & 26.2 & 21.7 & 18.1 & 21.4 & 19.5 & 6.6 & 3.8 \\
\hline SCU & 30 & 23.7 & 23.2 & 47.2 & 28.3 & 15.6 & 15.1 & 16.0 & 15.2 & 5.7 & 3.6 \\
\hline SC & 19 & 15.0 & 12.4 & 39.6 & 25.2 & 16.3 & 18.6 & 15.5 & 21.6 & 5.1 & 3.8 \\
\hline General ICU & 24 & 20.2 & 20.7 & 46.4 & 28.0 & 19.7 & 19.8 & 17.9 & 20.3 & 6.1 & 3.8 \\
\hline Neo ICU & 46 & 19.3 & 14.9 & 41.6 & 29.4 & 13.0 & 12.4 & 13.0 & 13.0 & 4.9 & 2.5 \\
\hline EN & 52 & 27.5 & 27.4 & 44.8 & 27.4 & 21.4 & 20.2 & 21.9 & 21.7 & 6.9 & 4.8 \\
\hline \multicolumn{12}{|l|}{ Job role } \\
\hline Nurse & 95 & 27.1 & 22.5 & 42.9 & 28.9 & 22.2 & 20.4 & 22.9 & 23.5 & 7.0 & 4.7 \\
\hline Nursing technician & 229 & 19.4 & 18.6 & 43.0 & 27.4 & 15.9 & 15.2 & 15.0 & 14.6 & 5.3 & 3.2 \\
\hline Nursing assistant & 31 & 16.8 & 16.2 & 51.7 & 29.7 & 13.0 & 14.4 & 9.1 & 12.4 & 4.7 & 2.8 \\
\hline \multicolumn{12}{|l|}{ Leadership position } \\
\hline Yes & 12 & 33.6 & 29.9 & 46.8 & 27.8 & 36.1 & 35.7 & 44.1 & 39.4 & 10.5 & 7.1 \\
\hline No & 83 & 20.1 & 19.1 & 42.8 & 28.2 & 16.4 & 15.6 & 15.3 & 15.5 & 5.4 & 3.4 \\
\hline
\end{tabular}

Note: OC - Obstetric Center; MAT - Maternity; PU - Pediatrics Unit; ES - Emergency Service; MCU - Medical Clinic Unit; SCU - Surgical Clinic Unit; SC - Surgical Center; General ICU - General Intensive Care Unit; Neo ICU - Neonatal Intensive Care Unit; EN - Emergency Network; WLQ - Work Limitations Questionnaire.

Table 4 - Significant differences between Work Limitations Questionnaire items and work characteristics of nursing workers, Rio Grande, Rio Grande do Sul, Brazil, 2020 (N=355)

\begin{tabular}{lccccc}
\hline & Management & Demand & WLQ \\
Variables & Time & Physical & Mental-Interpersonal & Production & ( \\
& $\boldsymbol{p}^{*}$ & $\boldsymbol{p}^{*}$ & $\boldsymbol{p}^{*}$ & $\boldsymbol{p}^{*}$ \\
\hline Working unit & $0.008^{\dagger}$ & 0.826 & $0.027^{\dagger}$ & $0.010^{\dagger}$ & $0.010^{\dagger}$ \\
Job role & $0.002^{\dagger}$ & 0.253 & $0.003^{\dagger}$ & $0.001^{\dagger}$ & $0.001^{\dagger}$ \\
Leadership position & $0.021^{\dagger}$ & 0.628 & $0.001^{\dagger}$ & $0.001^{\dagger}$ & $0.001^{\dagger}$ \\
\hline
\end{tabular}

Note: *ANOVA test; level of significance $p<0,05 ;$ WLQ - Work Limitations Questionnaire. 
The negative relationship between the psychological load was also verified using the item "Q22. Work excessively due to administrative, care and teaching, research and extension activities" and production demand $(r=-0.10, p<0.050)$. It was identified that, when the psychological burden of nursing workers increases, the limitation of production demand among them decreases, since the production demand is described as being able to complete all activities linked to work.

Table 5 - Pearson's correlation test between the Workload Scale in Nursing Activities and Work Limitations Questionnaire items, Rio Grande, Rio Grande do Sul, Brazil, 2020 (N=355)

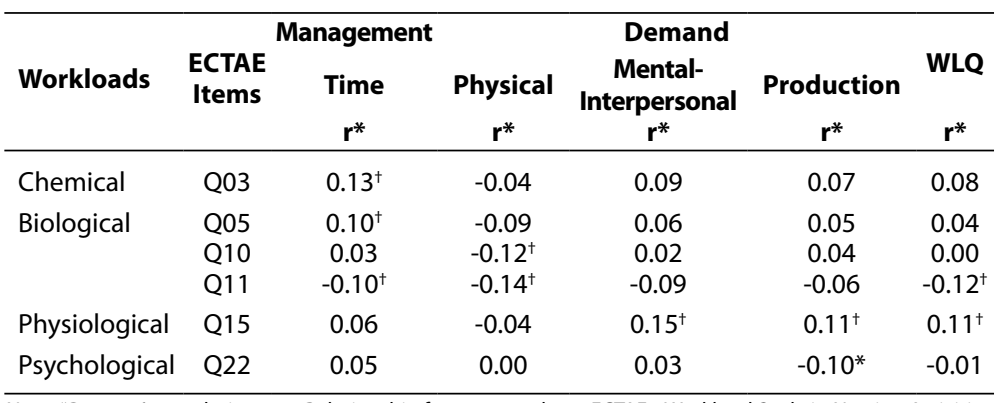

Note: *Pearson's correlation test; Relationship force $\geq-1$ and $\leq 1$; ECTAE - Workload Scale in Nursing Activities; WLQ - Work Limitations Questionnaire;

\section{DISCUSSION}

Nursing workers' exposure to workloads showed that biological loads were identified by workers as very intense in nursing activities. Physiological loads and chemical loads were identified as intense at work. These workloads represent how the nursing work process occurs in the hospital environment, in which activities involving patients, with exposure to biological materials, physical exertion and weight manipulation, are among the most exhausting routines at work ${ }^{(14)}$.

According to presenteeism, in the two university hospitals, there was a loss of productivity among nursing workers. Regarding WLQ domains, they presented greater limitation to physical demand, followed by time management. From a similar point of view, a study with 328 nurses highlights that workers who had poor health (50.0\%) had more experiences of presenteeism when compared to the group of nurses who had good health $(27.8 \%)^{(15)}$.

Corroborating the result of limitation for activities related to physical demand and time management, a study with 211 nursing workers from a teaching hospital who presented reduced work performance due to presenteeism manifested musculoskeletal symptoms, such as lumbar pain ${ }^{(16)}$. Presentist workers also report mental difficulties, exemplified by low concentration, difficulties in completing bureaucratic tasks and patient care ${ }^{(10)}$.

The units with the highest mean limitation in the WLQ domains and loss of productivity were the Emergency Network, the Emergency Care Service and the Medical Clinic Unit. These units present as a characteristic nursing care to patients who need urgent and emergency care, bedridden patients and palliative care, depending on the greater demand for nursing team's, favoring presenteeism.

Corroborating these results, a study with 62 workers from a multidisciplinary team of an Intensive Care Unit, $62.12 \%$ of which was from the nursing team, showed that presenteeism is related to the sociodemographic and labor characteristics of workers, such as gender, age, having dependent children, performing another professional activity, working hours, performing overtime and having already left work ${ }^{(9)}$.

The compromised health of workers is related to the reduction of the loss of productivity in nursing and has as factors that lead to the presentism the work stress, satisfaction, social support, human resources management, remuneration, training, autonomy and teamwork ${ }^{(17)}$. Health workers consider that the urgent hospital work environment has stressful activities and confirm attending work, even though they are sick, evidencing a high incidence of presenteeism ${ }^{(4)}$. It is noteworthy that the workplace has an influence on workers' health, being favorable environments for the implementation of health promotion initiatives, seeking to reduce presenteeism ${ }^{(18)}$.

According to workers'function, nurses were the most present, presenting greater loss of productivity, in addition to greater limitation in the domains of time management, mental and interpersonal demand and production demand. Additionally, nurses who held leadership positions had higher lost productivity than those who did not hold these positions.

In agreement with this result, a study highlights that presenteeism in the nursing team is identified in the professional category of nurses and that the option to attend work with some physical or psychological impairment occurs due to overload of functions, lack of support from supervisors ${ }^{(4)}$, financial conditions, tensions with the work team and guilt ${ }^{(10)}$. Furthermore, workers who hold positions at work, who need greater commitment, are not absent from work because of health problems ${ }^{(18)}$.

Confirming the influence of work characteristics of nursing workers with presenteeism, there was a significant difference between the items of WLQ time management, mental and interpersonal demand, production demand and productivity loss index and labor characteristics, working units, job role and leadership position. It is noteworthy that, given the exposure of nursing workers to factors, such as difficulty in resting and performing activities, the greater the possibility of developing work-related diseases, a situation aggravated by working conditions in which workers perform care ${ }^{(19)}$.

The relationship between workloads and presenteeism showed that the increase in chemical loads generates greater limitation in the domain of time management by nursing workers. This fact evidenced by the tasks performed by nursing and indirect patient care, which require time to be developed, which may lead to workers' inability to perform all work activities over a period of time. Chemical loads are characterized by the handling of chemicals, especially in the cleaning of materials. Exposure to these loads is attributed to health wear, such as nausea, dizziness and allergic reactions ${ }^{(20)}$.

The time limitation of workers was also evidenced by the relationship with chemical loads during the performance of activities that require the use of latex gloves and the limitation in the time management domain. Work in the hospital environment requires workers to use personal protective equipment 
due to exposure to biological agents, such as viruses, bacteria, fungi, among others. An example of this is coronavirus infection, in which nurses are at the forefront of patient care and are susceptible to contamination, which causes mental stress among workers, who require more time than usual to be cautious when placing and removing personal protective equipment in order to reduce the risk of infection ${ }^{(21)}$.

On the other hand, the increase in biological loads generates a decrease in limitation in the physical demand domain of workers. This fact may be related to the need that workers have to provide adequate care to patients, not letting physical health situations make it impossible to perform activities, such as dressings, care with drains and oral, nasal or tracheal aspiration. This result is justified, because presenteeism, besides resulting in poor performance and productivity in the workplace, also generates negative consequences for workers' health. Among the nursing team, presenteeism can compromise the care provided to the patient. At the same time, workers also compromise their health to promote patient care ${ }^{(7)}$.

This characteristic of the relationship between workloads and non-presenteeism among workers is also verified in the increase in biological loads related to the care of patients affected by microorganisms and contact precaution, aerosols and droplets and the reduction of limitation of time management, physical demand and loss of productivity. Considering the fact that, unquestionably, it is part of nursing work to act in situations that expose workers to biological loads. In a study in a Neonatal Intensive Care Unit, it was found that nursing workers highlighted exposure to secretions, viruses and bacteria, due to the care of people with infectious and transmissible diseases ${ }^{(20)}$.

The relationship between physiological loads and presenteeism is verified by the increase in mental-interpersonal demand limitations, production demand and loss of productivity in the face of exposure to these loads. This may be related to factors, such as not being able to fulfill activities, such as patient transportation, due to excessive work demands, also reflecting the possibility of a number of inadequate professionals or presentist workers. It is noteworthy that the nursing team assumes care and administrative activities, however the number of workers is not sufficient for the number of patients treated ${ }^{(22)}$.

Physiological loads are identified by nursing workers as performing repetitive movements, maintaining inadequate positions during procedures, staying for long periods in orthostatic position and manipulating patients' weights. In addition, they were characterized as responsible for musculoskeletal disorders and repetitive strain injuries ${ }^{(20)}$. A study showed that presenteeism affects a high number of nursing workers, manifested by musculoskeletal symptoms and causing decreased performance and concentration at work ${ }^{(16)}$.

The increase in exposure to psychological loads also showed a negative relationship with the production demand domain, describing an absence of limitation. Considering that the study was conducted in the context of university hospitals, workers are exposed to psychological burdens because they develop, at the same time, different activities, such as administrative, care and teaching, research and extension. However, it was not identified that these characteristics compromise the limitation for work.
Workers who develop activities with high physical, cognitive and social demands often ignore symptoms of physical and psychological illness and are not usually absent from health problems. This can be due to feeling responsible with work, developing various demands for prolonged periods without social support, characterizing them as presentist ${ }^{(18)}$. Therefore, presenteeism should be viewed as a managerial and care problem, as it reflects low productivity, situations of workers' dissatisfaction, increased incidents, stress, reduced quality of care, conflicts and illness ${ }^{(23)}$.

\section{Study limitations}

The cross-sectional design of this study is identified as a limitation, since it does not allow the analysis of cause and effect relationship as well as the performance in two work environments. Thus, it is suggested the reproduction of this study protocol in other university hospitals, in view of the need to discuss the theme among nursing workers from different regions of the country and/or hospitals with professional training character.

\section{Contributions to nursing}

The results of this study contribute to the nursing area by identifying the relationship of workloads in nursing activities and presenteeism among nursing workers, through two validated instruments. With them, important reflections are possible in relation to working conditions and activities inherent to the profession, which lead or not to nursing workers' presenteeism.

\section{CONCLUSIONS}

This study allowed identifying the relationship between workloads and presenteeism through two validated instruments. Presenteeism was identified through assessment of domains of limitation and loss of productivity, presenting a significant difference with the labor characteristics and their relationship with workloads of nursing activities.

Therefore, in the correlation between the variables, it was possible to verify which working conditions affect nursing workers' health, such as the handling of cleaning and disinfection products, equipment and materials, the use of latex gloves to perform invasive and noninvasive procedures in patients and the performance of patient transport and equipment.

However, it was also evidenced that there are working conditions that are so intrinsic to nursing activities, and even though they are workloads, they do not generate limitations and loss of productivity. As an example, to provide care to patients affected by microorganisms and patients in contact precaution, aerosols and droplets, to have contact with secretions and to work excessively due to administrative, care and teaching, research and extension activities.

The results obtained allow us to promote a focused look at working conditions and workloads that cause limitations and loss of productivity among nursing workers. With this, actions aimed at the recovery of health of workers who experience presenteeism can be developed. 


\section{REFERENCES}

1. Cargnin ZA, Schneider DG, Vargas MAO, Machado RR. Non-specific low back pain and its relation to the nursing work process. Rev LatinoAm Enfermagem. 2019;27:e3172. https://doi.org/10.1590/1518-8345.2915.3172

2. Laurell AC, Noriega M. Processo de produção e saúde: trabalho e desgaste operário. São Paulo: Hucitec; 1989.

3. Carvalho DP, Rocha LP, Tomaschewski-Barlem JG, Barlem ELD, Cecagno D, Dalmolin GL. Productivity versus workloads in the nursing working environment. Rev Esc Enferm USP. 2017;51:e03301. https://doi.org/10.1590/S1980-220X2017028903301

4. Baldonedo-Mosteiro M, Sanchez-Zaballos M, Rodriguez-Diaz FJ, Herrero J, Mosteiro-Diaz MP. Adaptation and validation of the Stanford Presenteeism Scale-6 in health care professionals. Int Nurs Rev. 2020;67:109-17. https://doi.org/10.1111/inr.12544

5. Mach M, Ferreira Al, Martinez LF, Lisowskaia A, Dagher GK, Perez-Nebra AR. Working conditions in hospitals revisited: a moderated mediated model of job context and presenteeism. PLoS ONE. 2018;13:e0205973. https://doi.org/10.1371/journal.pone

6. Brborović H, Daka Q, Dakaj K, Brborović O. Antecedents and associations of sickness presenteeism and sickness absenteeism in nurses: a systematic review. Int J Nurs Pract. 2017;23(6). https://doi.org/10.1111/ijn.12598

7. Rainbow JG, Steege LM. Presenteeism in nursing: An evolutionary concept analysis. Nursing Outlook. 2017;65(5):615-23. https://doi. org/10.1016/j.outlook.2017.03.005

8. Mosteiro-Díaz MP, Baldonedo-Mosteiro M, Borges E, Baptista P, Queirós C, Sánchez-Zaballos M, et al. Presenteeism in nurses: comparative study of Spanish, Portuguese and Brazilian nurses. Int Nurs Rev. 2020:1-10. https://doi.org/10.1111/inr.12615

9. Silva AF, Robazzi MLCC, Dalri RCMB, Silveira-Monteiro CA, Mendes AMOC. Presenteeism in multiprofissional team workers in the Adult Intensive Care Unit. Rev Bras Enferm. 2019;72(Suppl 10):96-104. https://doi.org/10.1590/0034-7167-2017-0779

10. Rainbow JG. Presenteeism: Nurse perceptions and consequences. J Nurs Manag. 2019;27:1530-7. https://doi.org/10.1111/jonm.12839

11. Hill MM, Hill A. Investigação por questionário. Lisboa: Editora Sílabo, 2002.

12. Lerner D, Amick BC, Rogers WH, Malspeis S, Bungay K, Cynn D. The Work Limitations Questionnaire. Med Care. 2001;39(1):72-85. https://doi. org/10.1097/00005650-200101000-00009

13. Dancey CP, Reidy J. Estatística sem matemática para psicologia. 5. ed. Porto Alegre: Penso, 2013. 608p.

14. Santana LL, Sarquis LMM, Miranda FMA, Kalinke LP, Felli VEA, Miniel VA. Health indicators of workers of the hospital area. Rev Bras Enferm. 2016;69(1):23-32. https://doi.org/10.1590/0034-7167.2016690104i

15. Jung SW, Lee JH, Lee KJ. Assessing the Association Between Emotional Labor and Presenteeism Among Nurses in Korea: cross-sectional Study Using the 4th Korean Working Conditions Survey. Saf Health Work. 2020;1(11):103-8. https://doi.org/10.1016/j.shaw.2019.12.002

16. Santos HEC, Marziale MHP, Felli VEA. Presenteeism and musculoskeletal symptoms among nursing professionals. Rev Latino-Am Enfermagem. 2018;26:e3006. https://doi.org/10.1590/1518-8345.2185.3006

17. Minjung K. EUnsuk C. Presenteeism in Clinical Nurses: an integrative literature review. Korean J Occup Health Nurs. 2017;26(3):160-71. https://doi.org/10.5807/kjohn.2017.26.3.160

18. Shimabuku RH, Mendonça H, Fidelis A. Presenteísmo: contribuições do Modelo Demanda-Controle para a compreensão do fenômeno. Cad Psicol Soc Trab. 2017;20(1):65-78. https://doi.org/10.11606/issn.1981-0490.v20i1 p65-78

19. Silva TPD, Araújo WN, Stival MM, Toledo AM, Burke TN, Carregaro RL. Musculoskeletal discomfort, work ability and fatigue in nursing professionals working in a hospital environment. Rev Esc Enferm USP. 2018;52:e03332. https://doi.org/10.1590/S1980-220X2017022903332

20. Michaello RS, Barlem JGT, Carvalho DP, Rocha LP, Bordignon SS, Neutzling BRS. Perception of nursing workers about the workloads in a neonatal intensive care unit. Rev Pesqui: Cuid Fundam. 2020;12:54-61. https://doi.org/10.9789/2175-5361.rpcfo.v12.6983

21. Huang L, Lin G, Tang L, Yu L, Zhou Z. Special attention to nurses' protection during the COVID-19 epidemic. Crit Care. 2020;24(120):1-3. https://doi.org/10.1186/s13054-020-2841-7

22. Bosco OS, Martins MS. Carga de trabalho da enfermagem influenciando a ocorrência e redução de lesões por pressão. Rev Nurs [Internet]. 2019 [cited 2021 Jun 30];22(250):2772-4. Available from: http://revistanursing.com.br/revistas/250/pg67.pdf

23. Moreira LG, Fernandes M. O Presenteísmo no âmbito da enfermagem em Unidade de Terapia Intensiva. Rev Pró-UniverSUS. 2019;10(1):15461. https://doi.org/10.21727/rpu.v10i1.1748 